\title{
Knowledge and Position: How to Manage Ambiguous Public Welfare Work'
}

\section{Chris Rønningstad ${ }^{2}$}

PhD fellow, Oslo Business School at Oslo Metropolitan University, Norway

\begin{abstract}
This study draws on 4 I interviews with managers and employees in the Norwegian public welfare services. The findings describe how employees in ambiguous semi-professional work experience frontline managers as knowledgeable. Underscoring the importance of managers with knowledge of the tasks at hand and field of work, the findings challenge existing theory on how managers support employees in discretionary work. An explanation for this may be found in the ambiguous, semi-professional setting requiring managerial input. The findings identify acts relevant for managing employees experiencing tensions between standardization and discretion.
\end{abstract}

\section{KEYWORDS}

Discretionary work / knowledge work / semi-professional organizations / management / leadership

\section{Introduction}

ublic welfare services, such as the local offices of the Norwegian Labour and Welfare Administration (Nav), are prime examples of bureaucratic organizations characterized by ambiguous work tasks where employees use their discretion to balance competing demands of care and accountability (Denis et al. 2015; Kirkpatrick \& Ackroyd 2003; Lawler \& Bilson 2009). The assumption is that managers of discretionary work gain authority from their practical knowledge of the tasks performed (Empson \& Langley 2015; Mintzberg 1979). However, semi-professional public welfare organizations such as Nav break with this assumption in that they do not require a professional education, experiences of professional logics are weakened, and managers do not necessarily possess a professional degree (Breit et al. 2017; Fossestøl et al. 2016a, p. 35; Øvrelid 2018).

Tasked with management and leadership, these managers enable employees in making discretionary decisions without the support of a standardized education. Hence, managers in semi-professional organizations represent an unexplored discontinuity of traditional assumptions regarding management of discretionary work. Unlike previous research, I am not concerned with identity-construction and logics (see Bolton 2005; Carvalho 2014; Olakivi \& Niska 2017), or how managers and employees make sense of competing logics (Andersson \& Liff 2018). Rather, my research aim is to describe how managers in these ambiguous, semi-professional p ublic welfare organizations, appear knowledgeable through their management and leadership acts. To achieve this, I pursued the following research question:

How do frontline managers in a semi-professional setting appear knowledgeable through their acts?

\footnotetext{
${ }^{1}$ You can find this text and its doi at https://tidsskrift.dk/njwls/index.

${ }^{2}$ Corresponding author: $\underline{\text { Chris.ronningstad@Oslomet.no. }}$
} 
The findings provide three main insights: (1) Managers in semi-professional, ambiguous bureaucracies do not rely solely on positional authority. To influence their employees, they require knowledge. (2) This knowledge can be understood as familiarity with the employees' job, knowledge about the organization and sector, as well as their own ability to do their job. (3) Combining knowledge and positional authority allows these managers to counteract ambiguity of the work by acting as 'motivational-controllers', 'resource allocators', and 'standardizers'. These acts provide managers with opportunities to motivate employees, acknowledge their contributions, and standardize ambiguous tasks.

Managers in this study worked on the frontlines of Nav and were responsible for the departments' performance. Employees worked with assessing applications and following up clients. Employees worked directly under the interviewed managers. Managers managed the office and did not carry their own list of clients. Lacking a standardized education and legal status, I consider employees in Nav knowledge workers rather than traditional professional actors. The term captures that they perform discretionary work by making decisions within rules and regulations in a bureaucratic system (Weber 2012/1904). This makes them similar to traditional professionals in requiring the use of discretion, but different in lacking the legal status and a standardized education to base their discretion on (Brante 2011). Lacking standardization opens up for managers drawing on different types of knowledge in their management and leadership acts.

I asked employees and managers about their experiences of managers' acts. This places the study within a research strand emphasizing knowledge as situated and practice-based (Gherardi 2001; Nicolini 2011; Orlikowski 2002). This is in accordance with followership perspectives on management and leadership (Alvesson 2017; Uhl-Bien et al. 2014). Seeing knowledge as 'practice-based' (Gherardi 2001; Nicolini 2011; Orlikowski 2002), I describe how employees appreciate managers as knowledgeable based on their management and leadership acts. The study rests on the ontology of practice theory in seeing the 'social world as brought into being through everyday activity’ (Feldman \& Orlikowski 2011, p. 1240-1241). Being concerned with practices is necessary to describe how actions constitute organizations (Lammi 2018, p. 9), in my case, by considering knowledge as a resource for managers performing management and leadership acts.

\section{Ambiguous public welfare work}

Although not the only work setting dealing with ambiguity, public welfare bureaucracies have some inherent ambiguous characteristics worth discussing in relation to management and leadership, described as a setting where employees draw on tacit and explicit knowledge to navigate grey areas (Blom et al. 2007; Dore 2018; Øverbye 2013). The environment is commanded by uncertainty, confusion, and doubt (Lawler \& Bilson 2009), with a 'high level of ambiguity in input, process, and output' (Buch \& Andersen 2013, p. 158).

Lacking a common knowledge-foundation, Nav-counselors are found to be uncertain of how to utilize their knowledge in their work, and they face difficulties applying discretion within the bureaucratic setting (Gjersøe 2016b). Even counselors with a professional education experience working in Nav as 'starting over', as they have to 
learn the system and what the job entails (Øvrelid 2018, p. 111-12). Tensions between bureaucratic routines, rules, and accountability (Weber 2012/1904) further complicate public bureaucracies by creating uncertainty about what decisions public servants are empowered to make.

$\mathrm{Nav}$ as a semi-professional organization in an ambiguous context is particularly relevant after the 2006 'Nav-reform' that merged municipal welfare, state welfare, and employment services into one organization. (for discussions on the insitutional logics behind this, see Breit et al.2017). The Nav reform intended departments to be general and cross-disciplinary (Andreassen \& Aars 2015, p. 93-94), not necessarily led by managers with professional degrees or having employees with specific professional educations. Despite efforts to 're-specialize' these offices (p. 94), they remain semi-professional, as professionally educated managers and employees with and without professional degrees work together in teams of generalists (Breit et al. 2017; Fossestøl et al. 2016a, p. 35). These employees make decisions based on individual discretion within the limits of rules and regulations. As such, Nav is similar to other bureaucratic organizations operating between organizational control and individual discretion (Weber 2012/1904). In being concerned with these issues, the findings are applicable to a wider set of similar public and private bureaucracies within the Nordic countries making discretionary decisions.

Nav-employees and managers are tasked with making discretionary decisions without a professional education to standardize the work or to impart professional status. $\mathrm{Nav}$ is characterized by bureaucratic ways of working, emphasizing routines, rationality, methods, and tools (Sagatun \& Smith 2012). Within a bureaucratic setting, it is limited by 'structural contingencies', such as standardized solutions, unclear delegation of tasks, control measures, and IT systems (Fossestøl et al. 2016b, p. 10-12). Professional social work knowledge is experienced as undervalued (Røysum 2010), a phenomenon that can be tied to a wider 'de-professionalization' of welfare work (Agevall \& Jonnergård 2007).

Bureaucratic principles gaining importance on professional ones appear in conjunction with new public management ideologies holding public services accountable for how they use their discretion and spend public money (Øverbye 2013). As a result, managers and employees in Nav and Swedish public welfare work admit to consider bureaucratic perspectives in their thinking and practices (Gjersøe 2016a; Røysum 2010; Shanks 2016). This follows a general development in the Nordic professional context (Alvehus \& Andersson 2018; Buch \& Andersen 2013; Kärreman et al. 2002). In Nav, professionally educated social workers experience control not as a threat, but as a contextualizing framework supporting their discretionary use (Øvrelid 2018). The clash between bureaucratic concerns and other perspectives is not new in 'professional bureaucracies' (Mintzberg 1979). However, Nav presents an interesting case study because rather than handling tension between a standardizing professional education and standardizing bureaucratic principles, managers now handle employees' or their own uncertainty about how to solve tasks. Doing this in a semi-professional organization, they lack a standardization of how to perform 'Nav-work' within bureaucratic rules and regulations.

Research on this situation has been concerned with the tensions between competing institutional logics, which describe different ways of thinking and doing in an organization (Friedland \& Alford 1991), mostly seen as a question of identity and sense-making among managers and employees (Breit et al. 2017; Buch \& Andersen 2013; Croft et al. 2015; Currie \& Spyridonidis 2016; Noordegraaf 2015; Olakivi \& Niska 2017). Curiously, little research exists on managers in this situation act and how employees 
consider them knowledgeable from these acts. Filling this gap, the study describes how employees within an ambiguous semi-professional work setting appreciate managers' as knowledgeable through their acts.

\section{Knowledge and managing ambiguous work}

Frontline managers hold a hierarchical position as formally responsible for departments and their employees. Managers plan, control, and coordinate (Alvesson et al. 2016, p. 95). Management as such concerns what a manager does (Hvenmark 2016), which may or may not include leadership behaviors influencing meaning making or realitydefinition through interpersonal behaviors (Alvesson et al. 2016). Managers perform a wide variety of acts related to the demands of their position. Colin Hales (2005) noted that managers in general perform supervisory, planning, and monitoring behaviors, while Mintzberg (1989) identified 10 different manager types. In this study, I identify how employees experience managers as knowledgeable through their acts. Rather than basing the analysis on these typologies, I inform the findings from the informants' own experiences and appreciation of acts where managers draw on their knowledge.

In being concerned with managers' performance of management and leadership acts, the study utilizes a practice-theoretical framework concerned with acts as their own unit of analysis (Lammi 2018, p. 12), in my case, by considering how managers draw on knowledge to perform management and leadership. Most leadership studies separate between knowledge, what you know, and skills, what you can do (Døving 2016). In accordance with a practice theoretical framework, I see knowledge as created through acts. Consequently, the managers are regarded as knowledgeable based on how they behave and not the source of this behavior.

Feldman and Orlikowski (2011) outline three principles of practice theory in line with my studies' contributions, the first being that everyday actions matter (p. 1241). Although the sort of consequence and influence differs (p. 1242), it means that acts have consequence and these consequences matter and are worth studying. This is relevant for my research as part of followership and implicit leadership-theories in management and leadership concerned with how acts are experienced (Alvesson 2017; Uhl-Bien et al. 2014). The second principle is that practice theory is interested in the dualism and not the polar opposites of phenomenon (p. 1242). This is recognizable in seeing how managers perform management and leadership from their position. The third principle is that actions and structural conditions are in an ongoing constitutive relationship (p. 1242), meaning that to understand actions one must be aware of the influencing context, as well as how these acts might influence the context back. This is exemplified by my concern with acts within the ambiguous semi-professional setting.

Managers of knowledge-intensive work draw their authority from knowing. They influence through their relationships with employees rather than through directives and interventions (Empson \& Langley 2015). Knowledge as situated and practice-based (Gherardi 2001; Nicolini 2011; Orlikowski 2002) makes managers' acts in interactions with employees important because knowledge is constituted as an ongoing social process of acts (Feldman \& Orlikowski 2011; Nicolini 2011; Orlikowski 2002). To inform the study, I review the literature on how employees in discretionary work experience managers as knowledgeable.




Despite the stated differences from professional work, I draw on theories from this field to inform the semi-professional setting. I apply this research strand despite of their differences because professionals and semi-professionals are similar in doing discretionary work. Leaning on this research is necessary due to it being an essential field of study regarding management of discretionary work. Leaning on this stream is also necessary because of the lack of specific semi-professional research. In this situation, we can learn from the best available research. I do this as a critical researcher by including research on knowledge work to inform the discussion, and making my own assessments on how the semi-professional setting might challenge the established literature.

By applying a practice theoretical framework, I am able to describe how employees appreciate their managers as knowledgeable through their acts, identify the relevant knowledge-inspiration behind these acts, and attribute this to the ambiguous semi-professional setting they work in. Below, I emphasize three relevant types of managers' knowledge: know-about others' work, know-how to do own tasks, and know-that about the public welfare setting and the rules and regulations of the organization.

\section{Know-about}

Know-about concerns what managers know about the employees' work. Traditionally, the term professional describes someone with a formal education performing an occupation with a solid knowledge base, status, income, and prestige, such as a medical doctor (Brante 2011). Even while performing ambiguous work, professionals need less managerial input because the work is standardized through their professional education (Mintzberg 1979). Consequently, professionally educated employees use their education as a 'guide to practice in future situations' (Emirbayer \& Johnson 2008, p. 4). Instead of relying on a decisive manager and hierarchical authority to intervene in the work, professionals coordinate skills and norms among each other, draw authority from their acquired expertise and values (Noordegraaf 2015, p. 190), leaving the manager to administer and coordinate the work.

The manager is not superfluous in these organizations; as a 'nerve-center' in the information-flow, they are expected to know more than their subordinates (Mintzberg 1989, p. 17). This makes know-about an essential inspiration for managers' acts. But rather than managers intervening in the performing of the work, it is believed that their know-about provides them with the authority to influence their employees' emotions and experiences (Empson \& Langley 2015). Schatzki (1996) writes on practices as the site where understanding is structured and intelligibility articulated (p. 12). In this regard, we should see employees' appreciation of the manager with know-about as rooted in his ability to understand the employee's actions.

As organizations experience that bureaucratic ideals of accountability become important to the detriment of professional values acquired through education, the base of power moves from the profession toward the manager (Kärreman et al. 2002). Combined with recruiting generalists, managers in Nav have experienced a need to intervene in the work to a degree that they must 'bureaucratize professional values to increase efficiency' (Breit et al. 2017, p. 13). This could mean that the inspiration for knowledge widens. As a result, employees in my study could be expected to appreciate the 
managers' know-that about the organizational and bureaucratic aspects of the organization as part of their know-about the employees work.

As employees in semi-professional organizations work less in relative isolation due to ambiguous work, they demand managers that rely on recognition, feedback, and clear frameworks (Buch \& Andersen 2013, p. 162). Such a development could mean that these managers are expected to help employees make decisions within the bureaucratic setting. I suspect that the lack of standardized education makes these semi-professional organizations susceptible to the increasing influence of rules and instructions. While a professional organization would call this know-about 'professional knowledge', I do not attribute semi-professional organizations with such a unified knowledge base. Rather, in line with the practice theory-perspective (Gherardi 2001), I expect that managers in their acts are inspired by multiple sources of knowledge. This would include knowledge about how to solve tasks and navigate different solutions within the public bureaucracy.

\section{Know-how and know-that}

Know-how is practical knowledge that managers display in doing their own job. It concerns acts showing the manager as analytical in handling complexity (Lombardo et al. 1988), having the ability to run meetings (Baran et al. 2011), or possessing the social competence to interact with employees (Mumford et al. 2007). Know-that not only concerns the contextual knowledge about the work and its surroundings, such as knowing them members of an organization (Mastekaasa 2008), but also wider knowledge about a sector's particularities (Lombardo et al. 1988).

Working with both municipal and state services, I expect Nav-managers to be appreciated by employees for their know-that about the public sector (Lagerløv 1999). Besides an increased emphasis on bureaucratic elements in semi-professional settings, I do not expect these types of knowledge to be very different from their ascribed utility for managers of other types of work. I expect technical knowledge about the organization and the managers' know-how about their own work to be also appreciated in semiprofessional work. It is likely that the three sources appear in combination, meaning that managers in semi-professional work could be experienced as knowledgeable in how they make informed decisions, perform as managers, and administrate the work.

\section{Methods}

This study draws on 41 interviews and field notes from 3-day visits of eight departments in Nav as a part of my doctoral project on management and leadership in public welfare work. I conducted the interviews in Norwegian and translated the quotations. In Norwegian, the words 'leader' (leder) and 'boss' (sjef) are often used interchangeably. To avoid confusion, I was careful to follow-up and clarify participants' use of these words during the interviews. My translations reflect as closely as possible the informants' intent. I conducted the interviews and transcriptions in spring and summer 2017, and coded the data using Nvivo Pro 11 for Windows. The Norwegian Centre for Research Data (NSD) approved the study. The selected quotes 
illustrated the findings of the analysis. I present them as illustrative examples of pattern in the data.

I asked employees how they experienced their managers' acts, and managers how they perceived their own acts. I deemed individual interviews the optimal method for describing individual experiences and appreciations. Individual interviews ensured that informants did not coordinate and appropriate experiences and appreciations from the group, but told their own stories. This methodology limited social desirability bias in which informants underreport undesirable behaviors (Edwards 1957). The interviews were a way to access the experiences of individual actors, and consequently, the findings are the result of my interpretations of informants' experiences of what managers do and how these acts influence them.

My contention is that managers are experienced through their acts in a shared social reality (Schutz 1962), with informants' experiences as a way of describing these behaviors (Bluhm et al. 2011, p. 1870). The inclusion of both managers' and employees' experiences provide a holistic view of the leader-follower relationship (Alvesson 2017; Uhl-Bien et al. 2014). This avoids the fallacy of a single perspective. Such an approach aligns with implicit leadership theory, which views leadership as interpreted through followers' experiences (Offermann \& Coats 2017). This view accounts for the fact that while the manager performs a hierarchical function, she is also positioned as performing acts by her employees (Davies \& Harré 1990).

The data include two different groups of employees-counselors and caseworkersas well as their managers as presented in Table 1. Counselors talk with clients face-toface and followed up on their progress and compliance in Nav's range of programs. Their job not only includes substantial personal interaction with clients but also considerable paperwork. Caseworkers, on the other hand, rarely meet face-to-face with clients, as their work entails evaluating data, deciding on each applicant's eligibility, and issuing written decision letters that follow a schematic form. Caseworkers were to a greater degree helped in their ambiguous tasks by laws, regulations, and circulars from the ministry about interpretations of these.

The two types of employees-those working closely with clients and those handling application assessments-provided a way to describe different workers' experiences of their managers. Similarities between the two indicate a general appreciation in an ambiguous semi-professional work setting, differences indicate how different work tasks might be an influence. Comparisons between offices performing the same work did not show any meaningful difference for this study's research aim. In another study (Rønningstad, 2019), I identified the influence of work tasks on the characteristics and behaviors that employees experienced as leadership from their managers. In this study, I drew on the same data to describe how managers utilize knowledge in their acts within a public welfare setting characterized by ambiguous work.

\section{Data collection and analysis}

As different areas of responsibility could influence managers' experiences, I visited departments that performed similar tasks within each category. I recruited informants from departments in cities and rural areas in seven Norwegian municipalities, selecting departments with between 10 and 20 employees to avoid the influence of very small 
Table I Characteristics of informants

\begin{tabular}{lcc}
\hline & Counselor & Caseworker \\
\hline Type of work & $\begin{array}{c}\text { Direct counseling with clients } \\
\text { Municipality }\end{array}$ & $\begin{array}{c}\text { Assessing eligibility to services } \\
\text { Owner }\end{array}$ \\
\hline No. of departments visited & 4 & 3 \\
\hline No. of managers & 5 & 4 \\
Social work educated/Other & $1 / 4$ & 0 \\
Jurist educated/Other & 0 & $2 / 2$ \\
Average age & 45 & 47.5 \\
Self-identifying females & 4 & 2 \\
Average years of experience & 15 & 13.75 \\
\hline No. of employees & 17 & 15 \\
Social work educated/Other & $8 / 9$ & 0 \\
Jurist educated/Other & 0 & $9 / 6$ \\
Average age & 36.1 & 40.1 \\
Self-identifying females & 16 & 10 \\
Average years of experience & 4.3 & 10.8 \\
\hline
\end{tabular}

or large units. Both counselor and caseworker departments were semi-professional in character. They had a high degree of employees with nonprofessional backgrounds, such as education in sociology and marine biology or work experience as a train conductor.

I recruited informants via email through managers for five scheduled interviews. In addition, I enlisted supplementary informants during my stays. This recruitment approach combined with asking informants to verify their voluntary participation ensured as much as possible that managers did not handpick informants according to their views. The 45- to 60-minute interviews were semi-structured, beginning with a set of prepared questions, but were flexible in the order of questions, exact phrasing, and follow-up. The interviews covered multiple aspects of management from the employees' and managers' perspectives, including employees' needs, their experiences of what managers do, and how it influenced them. Rather than introducing the concept of 'professional knowledge' during the interviews, I asked naive questions, such as 'How does your manager support you in your work?' As a critical interviewer, I asked informants to be specific about how they experienced these behaviors and how it influenced them. Therefore, the answers portray the informants' experiences and appreciations. In addition to asking follow-up questions to gauge the validity of the statements and have them elaborate on their experiences, I spent 3 days at each department observing, participating in meetings, and talking with all available cooperating personnel. This enabled me to scrutinize the answers in light of observed behaviors, contributing to more trustworthy results (Schaefer \& Alvesson 2017). Informants reported corresponding advantages and disadvantages with managers having or lacking knowledge, meaning that the identified benefits of having a knowledgeable manager mirrored the drawbacks of not having one. In reporting results, I anonymized each informant and office and referred to all with the female pronoun regardless of gender.

My findings are based on a close reading of responses linking manager-knowledge and acts. Starting out with a broad set of concepts, Mintzberg's (1989) typology was 
beneficial initially, but further into the analysis, I let the deciding factor be the informant's descriptions of the managers acts and the role of knowledge rather than the typology. Consequently, the typology provided an initially starting point, but did not determine the categorization of the acts. In this way, I could identify new acts fitting a new setting. I analyzed the data in three steps: first, identifying interview sections where informants discussed manager acts; second, revisiting and categorizing experiences and reasoning behind acts to ensure a correct categorization of each passage; and finally, identifying how acts were performed by examining the relationship between different types of acts and comparing counselors' and caseworkers' experiences.

\section{Knowledgeable managers}

Employees mentioned acts where managers drew upon the identified types of knowledge, often in combinations with each other or the managers' positional authority. Based on the responses, I conceptualize three types of acts presented in Table 2. The types describe how knowledgeable managers provided motivational feedback as motivational controllers and allocated tasks appropriately as recourse allocators. The standardizer is associated with acts where supportive and knowledgeable managers alleviated counselors' uncertainty about their work.

Table 2 Manager types and acts

\begin{tabular}{ll}
\hline Manager types & Acts \\
\hline Motivational controller & $\begin{array}{l}\text { Provide feedback on content and acknowledge contributions of } \\
\text { employees' production }\end{array}$ \\
\hline Resource allocator & Make informed decisions \\
\hline Standardizer & Remove ambiguity \\
\hline
\end{tabular}

\section{Motivational controller}

Employees and managers described that managers used their knowledge in performing traditional management tasks such as controlling work quality. Employees appreciated managers with enough know-about the tasks they performed to understand its nuances and provide feedback about the quality of work they performed:

I approved a vacation for a client. A-a auti-asperger, yes. That have been inside for all these years, and then he found out that now, now he needed to socialize. I thought, 'good, getting there' and approved vacation, grounded it well in legislation and-with my own arguments and-then I got praised, yes. Like: 'well done, you have used the legislation and, this is good!' [Counselor]

Managers were appreciated as motivating leaders when they used their knowledge to interact with employees and acknowledge the quality of their contributions. Knowing about the work employees performed allowed these managers to integrate supervision 
of work-quality with providing motivational feedback recognizing and acknowledging their efforts. Employees appreciated these acts because it enabled managers to integrate monitoring acts with being a motivational leader. This combination allowed managers to provide employees with feedback they experienced as meaningful:

(Manager) knows the field, and she ... has a certain idea about what is a lot and what is little, and which tasks demands what of you, and I believe that can be, or, I believe that is a positive. Because it leads to you getting feedback that is-they are meaningful and, you know you can go to her because she has an understanding. [Counselor]

Sharing the employees' experience, managers saw the potential opportunity of displaying know-about through monitoring behaviors. In doing so, they experienced that knowabout the work employees performed, enabled them to monitor information, identify pressing issues, and make changes when necessary:

Otherwise, I get, in a way, quite a good indicator of how they work, with all the requests I get every day, and the questions, makes me understand where the shoe pinches: 'Ok, then I realize that I've been ...' Like: 'You wonder about that, yes, we talked about that last week, too,'-'Eh'-'Yes, ok, what are you wondering about now, is it not the same thing again?' So it's that-it's almost that-that's where I get feedback about what's going on, yes. [Manager, Counselor]

Employees experienced that managers' authority eroded if they lacked know-about to identify erroneous decisions and provide appropriate correcting feedback. One example of this was managers who commended employees for the number of tasks they performed and not the quality of the work. Employees did not appreciate these types of quantitative feedback as motivating and saw these instances as indicative of managers lacking the knowledge to speak on the contents of the work. Consequently, managers who lacked the ability to recognize the quality behind employees' decisions failed to act as knowledgeable by providing feedback about the works' contents. When their comments failed to be appreciated as knowledgeable acts, it hurt their ability to influence employees as motivational controllers. For example, one caseworker described how receiving vague, general feedback was experienced as counterproductive and demotivating. Indicating that the managers lacked the know-about to provide precise comments:

There is little daily follow-up, yes. But she cannot come in to me and say 'yes, that case, how is it, should we discuss it, what is the problem there?' She cannot say that. So then we are left with few arenas, when she can only say-'hi' to me, 'how are you?' [Caseworker]

Managers combined monitoring and motivational acts in their capacity as formal quality-controllers. This allowed them the opportunities for interacting with employees. While some departments delegated such monitoring to the collegium, others ran this through the manager. Employees identified these interactions with managers as a structured way to get feedback about their work. Managers spoke positively about taking 
part in this approval process. They considered it an opportunity to understand the quality of employees' work and to identify pressing issues. As managers discovered instances where individual employees were doing well or struggling, they could use their knowabout to provide them positive feedback and support for making improvement:

I believe it is positive for those I approve for; I get close to them and can give some feedback about 'well written, this was good'-and also give them feedback on what I believe is not as good. [Manager, Casework]

Knowing about how employees performed their tasks enabled managers to provide effective feedback and aid employees' development even as they controlled to ensure the work met organizational standards and expectations. Informants' emphasis on managers combining controls on quality with feedback on quality represents a contrast to the traditional management of professionals performing discretionary work in 'relative isolation' (Noordegraaf 2015, p. 190). The increased concern with quantity could be attributable to the influence of bureaucratic principles such as accountability (Øverbye 2013; Weber 2012/1904). Despite of this bureaucratic influence, managers were not appreciated solely on the basis of their position. Employees showed an appreciation for managers who were able to combine their position with know-about and know-that to provide comments on the contents of their work, indicating that these managers were better equipped to motivate, as they merged the organization's need for accountability with the knowledge to support employees' need for feedback and acknowledgment.

\section{Resource allocator}

Employees appreciated managers with know-about and know-how who acted as resource allocators. These managers were proficient at allocating tasks appropriately and having realistic expectations for task completion. Employees appreciated these managers' ability to administer the work efficiently. Efficient managers combined knowabout the work and know-that of the setting with know-how of how to organize teams and delegate tasks. Managers experienced as lacking know-about or know-that were seen as having irrational expectations for the time necessary to complete a task. This created a rift between managers' demands and the employees' ability to fulfill them. Likewise, managers who lacked know-how to organize or administer the work properly frustrated employees. Managers themselves recognized that know-about was useful for their ability to be efficient resource allocators:

Because many of the discussions are about professional issues, and then in addition you must make some decisions about priorities. At the end of the day, you as a manager must make decisions about priorities. And then knowing what lies in the different tasks, andsome of the challenges of them, I think-I know is helpful. Also, just now, we have been given some new areas that we will work with. To then know something and see what, what may be of importance to the use of resources, it will probably be easier to say something about it, compared to if you do not know that much about it. [Manager, Casework] 
Employees appreciated managers who used know-that in the distribution of tasks, knowing how the work should be performed in the bureaucratic setting, and with the given resources. The benefits of know-that was apparent from informants who noted a particular appreciation for managers with contacts and knowledge of navigating the public bureaucracy, indicating that employees appreciated managers for their knowledge about the bureaucratic setting as well as know-about the work itself. To act as efficient allocators, managers had to efficiently combine these different types of knowledge. Managers unable to do so were experienced as unable to support or influence their employees:

\footnotetext{
So, we have a lot of professional expertise here, so there is enough professional support. What might be the biggest disadvantage with she not knowing our field is that she cannot ... when she distributes tasks she has no clue about how much, how advanced it is. She has learned some, so she can see it a little, but I think she does not even, even see the time perspective of a case, and sometimes she is making phone calls saying, 'yes, we can do it then and then, or we can, yes, it's for sure.' Then she comes (to us) and says, 'yes, it's probably easy', and then it isn't easy after all. Yes. I think she aspires to learn a little, but she has no time for it (laughter). [Caseworker]
}

Consequently, in describing motivational controller and resource allocator behaviors, counselors and caseworkers alike emphasized the manager's ability to draw on a combination of know-that, know-how, and know-about to make decisions and provide comments about the work, suggesting that employees in the semi-professional setting appreciated managers who drew on a combination of knowledge sources and using them in their management and leadership acts. However, employees differed in their need for managers intervening in their work based on the ambiguity of their worktasks.

\section{Standardizer}

In standardizing counselors' work, managers were appreciated for their ability to draw on knowledge in combination with their position as in charge of the department. This was most visible in standardizer acts, describing how counselors appreciated their managers' ability to combine their knowledge with the authority of the position. In instances where counselors were uncertain about the right course of action, the standardizer became necessary. Counselors appeared more appreciative of behaviors supporting them in making decisions in situations where they were unsure of what to do, either because of their difficult tasks, such as telling a client that their application will be rejected, or because they had issues identifying the best option of programs and aid within a Navsystem counselors especially experienced as unstandardized.

In experiencing more difficult-to-standardize situations, counselors differed from caseworkers in approaching their managers for advice to ensure that decisions were within their discretion, or to gain 'cover' to help them in these situations. Rather than relying on their gut feelings and potentially making erroneous decisions, counselors appreciated the ability to receive hierarchical support from the manager. Counselors had greater difficulties with determining the boundaries of their discretion than caseworkers. As an example, a counselor leaned on the manager's combination of know-about and 
know-that about the bureaucratic setting to decide whether a decision met ambiguous internal standards:

A difficult conversation, a rejection. In such situations I find it helpful to have talked with (manager) in advance, to get backing. Because, some of what we say in conversations (with clients) could easily end up in the newspapers. So, some of the rejections we give-and there we only see, we only read the client's version-we know there is much more behind it. But ... there I believe, in cases like that, difficult cases, I find it helpful to discuss it with (manager). I find her very good at making time for such situations, to actually listen. Because there are times where I need, to just be heard: 'What, what do you think? Am I thinking about this right? Can I say that? Is that okay?' Then she says: 'Take a breath, it is okay'. (Laughter) 'You're not doing anything illegal.' [Counselor]

The quote also illustrates how employees appreciated managers for their know-how by being good at communicating and listening. The expressed need for a standardizer among counselors suggest that ambiguous tasks, such as direct interactions with clients, may necessitate intervening managers to use a combination of their knowledge and position to identify the right decision. An example of this was a counselor with a social work degree describing the nonstandardized nature of the work and the difficulties in interpreting Nav rules and regulations:

I have not gotten any information about how to-how we think, in Nav, or what type of guidelines to apply. I have asked for it actually, eh-also regarding training, a bit like that — what to look for when writing a work-ability assessment? What will be the basis? Where can I find this information? [Counselor]

The appreciation for managers' input suggests that counselors sought support in their managers' hierarchical position in addition to their knowledge, either because they were unsure of how to-or preferring not to-stand accountable alone for the decisions they made. In either case, counselors appreciated being able to turn to managers for help in standardizing the work. Such behavior aligns with the bureaucratic ideals of accountability and authority, which rely on 'rules' or a higher hierarchical position as a standardizer of ambiguous work. As seen in the quotes, the extra step of seeking managerial support had two apparent benefits. It helped employees solve difficult cases, and 'inoculated' them from criticism in cases of uncertainty. Seeking support achieved this by enabling counselors to point to the hierarchical 'system' as the decision-maker. Managers noted that answering questions and providing cover for employees constituted a big part of their day, illustrating the need of these supportive behaviors in structuring the work:

Yes, it is the modus operandi throughout the day that they want a, they want feedback, quick feedback, and a decision in the moment. Yes: 'What do I do in that case?', 'How do I do that?' And then-I must simply just, I wish to, because I do not wish to sit and linger with things or say 'come back later', [speaking as to employees]: 'Yes okay, then I believe it is like that, I am not certain, but try it, or just do that, and do that.' Yes. [Manager, Counselor] 
In addition to using their know-about, know-that, and know-how in controlling and allocating tasks, managers were appreciated for their ability to combine knowledge and position in performing standardizing acts. Combining the two allowed managers to interact, motivate, and support employees in making decisions. Based on the informants' responses, I attribute the counselors' appreciation of such acts to the ambiguity of performing hard to standardize counseling-tasks. Unlike caseworkers, who received helpful standardization from a standardized bureaucracy in form of laws, regulations, and circulars, counselors were asked to use their discretion without any formal standardization besides the manager.

\section{Discussion}

This study identifies how frontline managers in Nav appear knowledgeable through their acts. It describes three types of acts where employees in semi-professional organizations appreciate managers' knowledge. Employees experienced knowledgeable managers as motivational in providing feedback and acknowledgement of the quality of their work, efficient at allocating tasks, and competent enough to standardize ambiguous work. In addition to the motivational boost of the motivational controller, the standardizer illustrates that frontline managers are important for standardizing ambiguous work tasks in a semi-professional setting without other sources of standardization.

In line with the increasing importance of bureaucratic principles of control and accountability in semi-professional welfare bureaucracies, these findings suggest that managers draw upon their hierarchical position in combination with their knowledge to integrate management and leadership acts. Based on this, I will discuss theoretical and practical implications of managing ambiguous work and combining knowledge with the manager positions' bureaucratic authority.

\section{Knowledge and managing ambiguous tasks}

This study represents a first in explicitly connecting manager acts and knowledge to the semi-professional setting of public welfare work. The identified manager types challenge the assumption that managers of discretionary work tend to facilitate more than intervene. Building on the work of Andersson and Liff (2018), Olakivi and Niska (2017), and Evetts (2011) regarding competing logics, this study identifies how managers in organizations with ambiguous tasks draw on their knowledge when performing management and leadership acts. The findings indicate that employees appreciate managers in semi-professional organizations drawing on multiple sources of knowledge. Whether or not counselors and caseworkers had a professional education did not seem to influence their appreciation of their managers as knowledgeable. This finding aligns with research showing $\mathrm{Nav}$ as an organization with a strong degree of internal training and employees relying on multiple sources of knowledge (Øvrelid, 2018).

The findings demonstrate that despite the dominance of bureaucratic perspectives in public welfare services such as Nav (Breit et al. 2017; Gjersøe 2016a; Øvrelid 2018), employees and managers of semi-professional welfare work appreciate managers with know-that, know-about, and know-how of the work. Acting with knowledge appears to 
support manager-employee interactions, as it enabled managers to interact with employees and acknowledge their contributions. While the recognition from being most knowledgeable might be weaker in semi-professional organizations like Nav (Røysum 2010), managers still appear to draw authority from their knowledge.

Explaining this, the findings suggest that employees expect managers in semiprofessional bureaucracies to possess know-that, know-how, and know-about to help them understand their position, acknowledge their contributions, and help them handle uncertainties. The ill-defined discretion-room of Nav-counselors may make standardizing support extra necessary for this type of work, suggesting that ambiguous work-tasks necessitate an involved manager drawing on their knowledge to standardize the work. Previous research on Nav has suggested that counselors need someone to structure their work (Gjersøe 2016a, 2016b). The finding supports this in describing counselors' appreciation for managers who can help standardize the work. It builds on this research by describing ways for managers to act in this capacity.

Manager's knowledge did not drive the need for these acts, rather it helped them fulfill an employee need created by ambiguous work tasks. Such a need might appear paradoxical in an organization like $\mathrm{Nav}$, described as centered on bureaucratic perspectives (Gjersøe,2016a; Røysum 2010). However, the findings suggest that while the organization is bureaucratized through demands of accountability, employees experience managers as an important standardizing force helping them conduct their work. I attribute this need to employees experiencing challenges with making decisions when interacting directly with clients in a complicated bureaucratic system, a challenge that can be explained by the lack of other standardizing functions such as a professional education or written instructions. Hence, my findings support theories on the relationship between standardization of work and managers' behaviors (Etzioni 1969; Mintzberg 1979; Thompson \& Vecchio 2009). My findings identify these theories as relevant for the ambiguous work of semi-professional welfare organizations. Additionally, my findings challenge them in saying that rather than the need for support being temporary, ambiguous work-tasks could create a stable need for standardizing managers.

The findings show that counselors used their discretion without the standardizing support of laws, regulations, and circulars that caseworkers received. In this situation, counselors appreciated managers with enough know-about and know-that of the work within the bureaucratic setting to standardize tasks that are not, or cannot, be standardized. For example, telling someone they will lose their income, or choosing which benefit-program a client can apply for if they fall somewhere between two options. The call for manager intervention occurred even when managers believed their involvement was unnecessary and represented more work for managers and employees. This raises a question for future research concerning whether managers, or organizations, fail to enable their employees to make decisions, or if tensions between bureaucratic accountability and discretion is an inherent complication of semi-professional organizations?

\section{Useful bureaucratic authority}

Employees appreciated managers who drew on their knowledge in combination with their formal position. This finding suggests that managers' authority may depend upon the combination of knowledge and position. Such an interpretation nuances the 
assumption that managers of discretionary work get their authority from their knowledge alone (Empson \& Langley 2015). Rather my findings show that managers in semi-professional welfare organizations combine different knowledge sources with the authority of their position.

The appreciations for monitoring behaviors could be a natural extension of an increased bureaucratic influence and emphasis on accountability (Øverbye 2013). Employees' need for the hierarchical backing of a knowledgeable 'boss' could be explained by the challenges they face in navigating an ambiguous field with competing demands. Uncertainty, and the potential for making a mistake, could lead employees to call for more bureaucracy to help them standardize tasks in grey areas between discretion and regulations (Øverbye 2013).

Semi-professional organizations integrate services and de-professionalize through broad recruitment of employees without requiring a standardizing education. In this situation, employees appreciated managers who were able to combine know-how, know-about, and know-that. The appreciation for standardization actualizes the utility of managers who are able to combine their knowledge with the authority of their positions to execute control and standardization. The findings are relevant to the discussion about whether management is a general skill or a matter of specific competence (Døving 2016). The finding calls into question the 'general manager' approach, which maintains that managers are universally capable of leading based on their general qualifications. In semi-professional organizations with ambiguous work tasks, such as Nav, employees appear to appreciate managers with enough knowledge about the specifics of the work to lessen the distance between authority and knowledge. The findings suggest that the ability to integrate knowledge with a position of authority could make frontline managers better leaders because they can combine controlling and motivating interactions.

Although I do not suggest that managers without this knowledge are ineffectual managers, this study underscores some apparent practical benefits with frontline managers who can handle the contents of ambiguous tasks and provide needed standardization. In organizations similar to Nav-those with unclear expectations, competing demands, and ambiguous tasks-managers would benefit from combining their formal position with detailed knowledge of the work, the setting, and how to perform management tasks. I expect that employees of similar organizations would share the need for a knowledgeable manager to control quality, delegate tasks, and structure the work. My finding aligns with theories on practice-based knowledge by describing how knowledge occurs in interactions between managers and employees (Nicolini 2011, p. 617). Complementary to previous research (Kärreman et al. 2002), this study indicates how employees of semi-professional organizations experience a shift in power toward managers by describing the need for a standardizing force.

The need for knowledgeable managers raises an important question: If these organizations fail to recruit managers with knowledge to uphold the standardizing function, who will uphold these standards? While public welfare departments often have advisors overseeing the professional contents of the work, employees continuing to seek managers' support may indicate that these advisors lack the necessary combination of knowledge and position to be effective. If employees experience difficulties with knowing what they are allowed or supposed to do, knowledge or position alone is not enough. The findings indicate that employees need a knowledgeable manager who can combine the power to determine what they may do, with the knowledge to say what they should do.

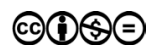




\section{Conclusion}

To answer the research question, the study finds that frontline managers in the semiprofessional setting appear knowledgeable in acts where they control, allocate, and standardize the work. The findings make three contributions to our knowledge about how to manage ambiguous work in semi-professional organizations:

First, the study presents three ways in which managers handle ambiguity by drawing on their knowledge to control and motivate employees, allocate resources of the office, and standardize ambiguous tasks. Second, the study indicates that managers draw on know-about, know-how, and know-that in combination to do so. Third, employees appreciate managers with the knowledge and positional authority to help them make discretionary decisions within an ambiguous bureaucratic setting.

While these findings differ with theories on what managers of professionals do, they do not contradict theories on how managers in general behave (Hales 2005). I attribute this finding to the development of a semi-professional landscape muting professional aspects and reducing differences between public welfare bureaucracies and other organizations (Alvehus \& Andersson 2018; Evetts 2011).

My findings suggest ways in which this development influences how employees experience managers as knowledgeable through their acts. The study offers some noteworthy details on how managers rely on their knowledge to support employees. I suggest two reasons transferable to other organizations for why employees in semi-professional settings appreciate managers with such knowledge. First, the ambiguity of the work creates a need for a manager who knows the practical intricacies of the work. Second, employees in semi-professional organizations lacking clear instructions and standardizing education need the manager to be a standardizing bureaucratic force employees can lean on to make correct decisions.

\section{References}

Agevall, L. \& Jonnergård, K. (2007). 'Management by documents-A risk of de-professionalizing' in Aili, C., Nilsson, L.-E., Svensson, L. G. \& Denicolo, P. (eds.) The Tension Between Organization and Profession, Lund, Sweden: Nordic Academic Press.

Alvehus, J. \& Andersson, T. (2018). A new professional landscape: entangled institutional logics in two Swedish welfare professions, Nordic Journal of Working Life Studies 8(3). doi: http://dx.https://doi.org/10.18291/njwls.v8i3.109542.

Alvesson, M. (2017). Leadership: convergence and divergence in leadership relations, Journal of Management Inquiry 1-17. Advance online publication. doi: http://dx.doi. org/10.1177/1056492617717339.

Andersson, T. \& Liff, R. (2018). Co-optation as a response to competing institutional logics: professionals and managers in healthcare, Journal of Professions and Organization 5(2): 71-87. doi: http://dx.doi.org/10.1093/jpo/joy001

Andreassen, T. A. \& Aars, J. (2015). Den store reformen: Da NAV ble til [The Great Reform: When NAV Was Created], Oslo: Universitetsforlaget.

Baran, B. E., Shanock, L. R., Rogelberg, S. G., \& Scott, C. W. (2011). Leading group meetings: supervisors' actions, employee behaviors, and upward perceptions, Small Group Research 43(3): 330-355. doi: http://dx.doi.org/10.1177/1046496411418252.

Blom, B., Nygren, L., Nyman, C. \& Scheid, C. (2007). Social work students' use of knowledge in direct practice-reasons, strategies and effects, Social Work \& Society 5(1): 46-61. 
Bluhm, D. J., Harman, W., Lee, T. W. \& Mitchell, T. R. (2011). Qualitative research in management: a decade of progress, Journal of Management Studies 48(8): 1866-1891. doi: http://dx.doi.org/10.1111/j.1467-6486.2010.00972.x.

Bolton, S. C. (2005). 'Making up'managers: the case of NHS nurses, Work, Employment \& Society 19(1): 5-23. doi: http://dx.doi.org/10.1177/0950017005051278.

Brante, T. (2011). Professions as science-based occupations, Professions and Professionalism 1(1): 4-20. doi: http://dx.doi.org/10.7577/pp.v1i1.147.

Breit, E., Fossestøl, K. \& Andreassen, T. A. (2017). From pure to hybrid professionalism in post-NPM activation reform: the institutional work of frontline managers, Journal of Professions and Organization 5(1): 28-44. doi: http://dx.doi.org/10.1093/jpo/jox013

Buch, A. \& Andersen, V. (2013). (De)stabilizing self-identities in professional work, Nordic Journal of Working Life Studies 3(3): 155-174. doi: http://dx.doi.org/10.19154/njwls. v3i3.3016.

Carvalho, T. (2014). Changing connections between professionalism and managerialism: a case study of nursing in Portugal, Journal of Professions and Organization 1(2): 176190. doi: http://dx.doi.org/10.1093/jpo/jou004.

Croft, C., Currie, G. \& Lockett, A. (2015). Broken 'two-way windows'? An exploration of professional hybrids, Public Administration 93(2): 380-394. doi: http://dx.doi.org/ 10.1111/padm.12115.

Currie, G. \& Spyridonidis, D. (2016). Interpretation of multiple institutional logics on the ground: actors' position, their agency and situational constraints in professionalized contexts, Organization Studies 37(1): 77-97. doi: http://dx.doi.org/10.1177/017084061 5604503.

Davies, B. \& Harré, R. (1990). Positioning: the discursive production of selves, Journal for the Theory of Social Behaviour 20(1): 43-63. doi: http://dx.https://doi.org/10. 1111/j.1468-5914.1990.tb00174.x.

Denis, J. L., Ferlie, E. \& Van Gestel, N. (2015). Understanding hybridity in public organizations, Public Administration 93(2): 273-289. doi: http://dx.doi.org/10.1111/padm. 12175.

Dore, I. (2018). Social work on the edge: not knowing, singularity and acceptance, European Journal of Social Work 1-12. Advance online publication. doi: http://dx.doi.org/10.1080 /13691457.2018.1463971.

Døving, E. (2016). 'Fagfolk og generalister som ledere i profesjonelle organisasjoner [Professionals and generalists as leaders in professional organizations]' in Døving, E., Elstad, B. \& Storvik, A. (eds.) Profesjon og Ledelse, Bergen: Fagbokforlaget.

Edwards, A. L. (1957). The Social Desirability Variable in Personality Assessment and Research, Ft Worth, TX: Dryden Press.

Emirbayer, M. \& Johnson, V. (2008). Bourdieu and organizational analysis, Theory and Society 37(1): 1-44. doi: http://dx.doi.org/10.1007/s11186-007-9052-y.

Empson, L. \& Langley, A. (2015). 'Leadership and professionals: Multiple manifestations of influence in professional service firms' in Empson, L., Muzio, D., Broschak, J. P. \& Hinigs, B. (eds.) The Oxford Handbook of Professional Service Firms, Oxford: Oxford University Press.

Etzioni, A. (1969). The Semi-professions and Their Organization: Teachers, Nurses, Social Workers, New York: Free Press.

Evetts, J. (2011). A new professionalism? Challenges and opportunities, Current Sociology 59(4): 406-422.

Feldman, M. S., \& Orlikowski, W. J. (2011). Theorizing practice and practicing theory, Organization Science 22(5): 1240-1253.

Fossestøl, K., Breit, E. \& Borg, E. (2016a). Betingelser for sosialt arbeid. En case- og surveystudie fra fem storbyer og syv storbykontorer. [Contingencies for Social Work]. AFIreport 2016(2), Oslo: Work Research Institute, HiOA. 
Fossestøl, K., Breit, E. \& Borg, E. (2016b). Hvorfor lykkes ikke NAV-kontorene med å jobbe mer arbeidsrettet? [Why are NAV offices not successsful in being more work-oriented?], Søkelys på Arbeidslivet 1(2): 5-23. doi: http://dx.doi.org/10.18261/issn.1504-79892016-01-02-01.

Friedland, R. \& Alford, R. R. (1991). 'Bringing society back in: Symbols, practices and institutional contradictions' in Powell, W. W. \& Dimaggio, P. J. (eds.) The New Institutionalism in Organizational Analysis, Chicago: University of Chicago Press.

Gherardi, S. (2001). From organizational learning to practice-based knowing, Human Relations 54(1): 131-139. doi: http://dx.https://doi.org/10.1177/0018726701541016.

Gjersøe, H. M. (2016a). Getting sick and disabled people off temporary benefit receipt: strategies and dilemmas in the welfare state's frontline, Nordic Journal of Working Life Studies 6(S1): 129-145. doi: http://dx.doi.org/10.19154/njwls.v6i1.4889.

Gjersøe, H. M. (2016b). Vurdering av arbeidsevne i NAV: Et spørsmål om kunnskap? [Work ability assesment in NAV: a question of knowledge?], Sosiologi i Dag 46(1): 9-31.

Hales, C. (2005). Rooted in supervision, branching into management: continuity and change in the role of first-line manager, Journal of Management Studies 42(3): 471-506.

Hvenmark, J. (2016). Ideology, practice, and process? A review of the concept of managerialism in civil society studies, VOLUNTAS: International Journal of Voluntary and Nonprofit Organizations 27(6): 2833-2859.

Kirkpatrick, I. \& Ackroyd, S. (2003). Transforming the professional archetype? The new managerialism in UK social services, Public Management Review 5(4): 511-531. doi: http://dx.doi.org/10.1080/1471903032000178563.

Kärreman, D., Sveningsson, S. \& Alvesson, M. (2002). The return of the machine bureaucracy? Management control in the work settings of professionals, International Studies of Management \& Organization 32(2): 70-92. doi: http://dx.doi.org/10.1080/00208825.2002. 11043661.

Lagerløv, S. (1999). Forvaltningshåndboka: utvalgte emner for saksbehandlere og ledere i stat og kommune. [Governance handbook], Oslo: Ad Notam Gyldendal.

Lammi, I. J. (2018). A practice theory in practice: Analytical consequences in the study of organization and socio-technical change. Doctoral thesis 190, Företagsekonomiska institutionen: Uppsala University.

Lawler, J. \& Bilson, A. (2009). Social Work Management and Leadership: Managing Complexity with Creativity, London: Routledge.

Lombardo, M. M., Ruderman, M. N., \& McCauley, C. D. (1988). Explanations of success and derailment in upper-level management positions, Journal of Business Psychology 2(3): 199-216.

Mastekaasa, A. (2008). Profesjon og Arbeidsmarked [Profession and the Labor Market] in Molander, A. \& Terum, L. (eds.) Profesjonsstudier I, Oslo: Universitetsforlaget.

Mintzberg, H. (1979). The Structuring of Organizations, London: Pearson.

Mintzberg, H. (1989). Mintzberg on Management: Inside Our Strange World of Organizations, New York: Simon and Schuster.

Mumford, T. V., Campion, M. A., \& Morgeson, F. P. (2007). The leadership skills strataplex: leadership skill requirements across organizational levels, The Leadership Quarterly 18(2): 154-166.

Nicolini, D. (2011). Practice as the site of knowing: Insights from the field of telemedicine, Organization Science 22(3): 602-620. doi: http://dx.https://doi.org/10.1287/orsc.1100.0556.

Noordegraaf, M. (2015). Hybrid professionalism and beyond: (New) forms of public professionalism in changing organizational and societal contexts, Journal of Professions and Organization 2(2): 187-206. doi: http://dx.doi.org/10.1093/jpo/jov002.

Offermann, L. R. \& Coats, M. R. (2017). Implicit theories of leadership: stability and change over two decades, The Leadership Quarterly 29(4): 513-522. doi: http://dx.doi. org/10.1016/j.leaqua.2017.12.003. 
Olakivi, A. \& Niska, M. (2017). Rethinking managerialism in professional work: from competing logics to overlapping discourses, Journal of Professions and Organization 4(1): 20-35. doi: http://dx.doi.org/10.1093/jpo/jow007.

Orlikowski, W. J. (2002). Knowing in practice: enacting a collective capability in distributed organizing, Organization Science 13(3): 249-273. doi: http://dx.https://doi.org/10.1287/ orsc.13.3.249.2776.

Øverbye, E. (2013). 'Velferdsprofesjoner i aktiveringsstaten: En studie av ambivalente relasjoner [Welfare-professions in the activation state: Ambivalent relations]' in Molander, A. \& Smeby, J. C. (eds.) Profesjonsstudier II, Oslo: Universitetsforlaget.

Øvrelid, B. (2018). Profesjonsidentitetens vilkår [Terms for professional identity], Tidsskrift for Velferdsforskning 21(02): 103-118. doi: http://dx.doi.org/10.18261/issn.2464-30762018-02-02.

Rønningstad, C. (2019). How unstandardized work tasks create arenas for leadership, Human Service Organizations: Management, Leadership \& Governance 1-14. Advance online publication. doi: http://dx.doi.org/10.1080/23303131.2019.1610130.

Røysum, A. (2010). Nav-reformen: Sosialarbeidernes profesjon utfordres [Nav-reform: challenges to the social worker profession], Fontene Forskning 1(10): 41-52.

Sagatun, S. \& Smith, E. (2012). 'Aktivt medvirkende og medansvarlige brukere i sosialtjenesten og NAV [Active complicity and co-responsible users in social services and NAV]' in Jenssen, A. G. \& Tronvoll, I. M. (eds.) Brukermedvirkning: Likeverd og anerkjennelse, Oslo: Universitetsforlaget.

Schaefer, S. M. \& Alvesson, M. (2017). Epistemic attitudes and source critique in qualitative research, Journal of Management Inquiry. Advance online publication. doi: http://dx.doi. org/10.1177/1056492617739155.

Schatzki, T. (1996). Social Practices: A Wittgensteinian Approach to Human Activity and the Social, Cambridge: Cambridge University Press. http://dx.doi.org/10.1017/ CBO9780511527470.

Schutz, A. (1962). 'Common-sense and scientific interpretation of human action' in Natanson, M. (ed.) Collected Papers I, Dordrecht, The Netherlands: Springer.

Shanks, E. (2016). Managing Social Work: Organisational Conditions and Everyday Work for Managers in the Swedish Social Services. Doctoral thesis 33, Stockholm University.

Thompson, G. \& Vecchio, R. P. (2009). Situational leadership theory: a test of three versions, The Leadership Quarterly 20(5): 837-848. doi: http://dx.doi.org/10.1016/j.leaqua.2009.06.014.

Uhl-Bien, M., Riggio, R. E., Lowe, K. B. \& Carsten, M. K. (2014). Followership theory: a review and research agenda, The Leadership Quarterly 25(1): 83-104. doi: http://dx.doi. org/10.1016/j.leaqua.2013.11.007.

Weber, M. (2012/1904). 'Byråkrati [Bureaurcacy]' in Fivelstad, E. (ed.) Max Weber-Makt og Byråkrati [Max Weber-Power and Bureaucracy], Oslo: Gyldendal Akademisk. 